\title{
Changes in IGF-I and -II, IGF Binding Protein, and IGF Receptor Transcript Abundance after Uterine Artery Ligation
}

\author{
WAYNE A. PRICE, LIU RONG, ALAN D. STILES, AND A. JOSEPH D'ERCOLE \\ Department of Pediatrics, University of North Carolina at Chapel Hill, Chapel Hill, North Carolina 27599
}

\begin{abstract}
Altered IGF activity may be one mechanism involved in the pathogenesis of intrauterine growth retardation (IUGR). We assessed the expression of IGF, IGF binding protein (IGFBP), and IGF receptor transcripts in liver, carcass, and placenta of fetal rats with IUGR resulting from unilateral uterine artery ligation. We found that uterine artery ligation on d $\mathbf{1 7}$ of gestation resulted in reduced body weight, liver weight, and placental weight on d 20 in the fetuses from the ligated uterine horn (UA-lig) compared with those from the opposite, nonligated uterine horn (UA-nonlig) and those from dams with no surgery or anesthesia. As assessed by solution hybridization, UA-lig fetuses exhibited significantly higher hepatic IGFBP-1, IGFBP-2, and IGF-II transcript abundance than UA-nonlig controls (increased 110, 50, and 31\%, respectively). The only major difference among groups in carcass and placenta mRNA abundance was a $44 \%$ decrease in placental IGFII expression in UA-lig pups compared with pups from dams that had had no surgery or anesthesia. Serum IGFBP, analyzed by ligand blot, showed a 2.4-fold increase in the doublet IGFBP-1/-2 band in UA-lig fetuses. Serum immunoreactive IGFBP-2 was unchanged among the groups, indicating that IGFBP-1 accounted for the increase in doublet intensity. Our results suggest that increased serum IGFBP-1 concentrations may decrease IGF activity in serum and thus inhibit IGF-stimulated cell proliferation or, by crossing the endothelial border, inhibit the activity of locally produced IGF. Decreased IGF-II expression in placenta also may contribute to decreased placental growth and, in turn, to IUGR. Our observations, therefore, suggest that IUGR in fetal rats with restricted arterial blood supply may be, in part, due to decreased IGF bioavailability and activity. (Pediatr Res 32: 291-295, 1992)
\end{abstract}

\section{Abbreviations}

IGFBP, insulin-like growth factor binding protein IUGR, intrauterine growth retardation

UAL, uterine artery ligation

nonop, no operation, no anesthesia

UA-nonlig, uterine artery not ligated

UA-lig, uterine artery ligated

CRL, crown-rump length

TNA, total nucleic acid

PCR, polymerase chain reaction

Received March 2, 1992; accepted May 11, 1992

Correspondence and reprint requests: Wayne A. Price, M.D., Dept. of Pediatrics, CB \#7596 Ath Floor UNC Hospital, Chapel Hill, NC 27599.

Supported by Grants HD08299 (A. J. D.) and HL38902 (A. D. S.) from the NIH and by March of Dimes Basic Research Grant 1-758 (A. J. D.). Dr. Price is a recipient of a Fellowship Award from the American Lung Association and the $\mathrm{T}$. H. Davis Fellowship Award from the American Lung Association of North Carolina. Dr. Stiles is the recipient of a Basil O'Conner Career Starter Grant from the March of Dimes.
IGF-I and -II are synthesized in multiple fetal tissues and are thought to participate in the autocrine/paracrine stimulation of cellular proliferation and differentiation during development (1). Decreased IGF action has been implicated in the pathophysiology of fetal growth retardation resulting from a number of etiologies. In man, IUGR has been associated with a reduction in serum concentrations of immunoreactive IGF-I and IGF bioactivity (1). Animal models of IUGR caused by a decrease in fetal nutrient intake also demonstrate decreased fetal serum immunoreactive IGF-I and IGF bioactivity (2-5). A potential mechanism for the alterations in IGF bioactivity might include changes in IGFBP expression.

Six IGFBP have been identified and characterized thus far (IGFBP 1-6) (6-11). In many situations, IGFBP appear to decrease IGF activity by sequestering free IGF in serum (12). IGFBP also may modulate IGF activity by altering the interaction between the IGF and the type 1 IGF receptor at the cell surface, thereby either inhibiting or augmenting IGF actions (13). Moreover, IGFBP appear to be regulated in a tissue-specific fashion $(14,15)$ and may participate in the local regulation of organ growth. For example, we found an increase in liver and lung IGFBP-1 mRNA in growth-retarded fetal rats after maternal dexamethasone administration (16). Increased local expression of IGFBP-1 could account for the marked organ growth retardation found in this model

UAL provides a model of uteroplacental insufficiency and the IUGR that results, in part, from nutrient deprivation $(17,18)$. A number of studies have demonstrated that UAL-growth-retarded fetuses have decreased serum IGF bioactivity, decreased serum immunoreactive IGF-I, and increased serum IGFBP-1 (19-22). None of these studies, however, examined whether local alterations in the production of IGF or IGFBP were implicated in the decreased cell proliferation observed in specific tissues. The purpose of this study was to evaluate the role of IGF in the growth regulation of visceral, somatic, and extraembryonic tissue from UAL-growth-retarded fetuses by assessing steady-state mRNA transcript abundance for IGF-I, IGF-II, the type 1 and type 2 IGF receptors, and IGFBP 1-5.

\section{MATERIALS AND METHODS}

Pregnant Sprague-Dawley rats of known gestational age were purchased from Hilltop Laboratories (Scottdale, PA). The dams were housed separately and fed ad libitum. On gestation d 17, dams were anesthetized with ketamine $(2.5 \mathrm{mg} / 100 \mathrm{~g})$ and UAL were performed by placement of a single silk ligature around the uterine artery supplying one uterine horn (UA-lig horn) (23). The uterine vasculature on the opposite horn was left undisturbed to obtain operated control animals without uterine artery ligation (UA-nonlig horn). The uterus was returned to the abdominal cavity and the incision closed. Two dams had no anesthesia and no surgery to evaluate the effects of decreased perioperative nutrient intake on the fetuses (nonop animals). On 
gestation $\mathrm{d} 20$, the dams were anesthetized with ketamine and fetuses of known uterine position (position 1 designates the position closest to the uterine introitus whether or not this position was occupied by a viable fetus) were removed through a full-length abdominal incision. UAL was performed on 18 pregnant rats, of which seven had sufficient pups on each side for appropriate analysis (three litters were excluded because of an insufficient number of pups in one uterine horn and eight were excluded because of excessive fetal wastage). The weight and CRL of each fetus was determined and serum was collected from the trunk after decapitation. The placenta and the liver were dissected and the fetal carcass was collected after removal of all remaining organs. All tissues were immediately immersed in liquid nitrogen and stored at $-70^{\circ} \mathrm{C}$ until use. Serum was stored at $-20^{\circ} \mathrm{C}$ until use. This protocol was approved by the Animal Use Committee of the University of North Carolina at Chapel Hill and was conducted in accordance with the guidelines of the National Institutes of Health.

TNA preparation. TNA samples for solution hybridization assays were prepared from frozen tissues $(\sim 200 \mathrm{mg})$ as previously described (4). Tissue was homogenized, incubated in a solution of $0.2 \mathrm{mg} / \mathrm{mL}$ proteinase $\mathrm{K}$ and $1 \% \operatorname{SDS}$ at $65^{\circ} \mathrm{C}$ for $1 \mathrm{~h}$, then precipitated in ethanol after phenol-chloroform extraction (24). TNA concentration was measured by spectrophotometry (Beckman DU-65 spectrophotometer, Fullerton, CA) and DNA by a fluorometric method using a TKO 100 fluorometer (Hoefer Scientific Instruments, San Francisco, CA).

Hybridization riboprobes and standards. Complementary DNA were cloned into the plasmid vectors pBS M13+ or pBluescript SKII+ (Stratagene Cloning Systems, San Diego, CA). Antisense riboprobes (complementary to mRNA sequences) were prepared by in vitro transcription using uridine $5^{\prime}-\left[\alpha-{ }^{32} \mathrm{P}\right]$ triphosphate (Amersham Corp., Arlington Heights, IL) and T3 or T7 DNA-dependent RNA polymerase, depending on the orientation of the cDNA insertion. Nonradiolabeled sense sequences, identical with mRNA sequences, were generated for use as standards in solution hybridization assays.

The IGF-I riboprobe was generated from a 194-bp AvaII-HinfI fragment (bp 379-573, exon 3) of a rat IGF-I cDNA (25). An IGF-II riboprobe complementary to $241 \mathrm{bp}$ of the E-domain and $34 \mathrm{bp}$ of the $3^{\prime}$ untranslated region was derived from a 275-bp $R s a$ I fragment of rat IGF-II cDNA (a gift from H. J. Whitfield and M. M. Rechler, National Institutes of Health, Bethesda, MD) (26). The rat type 1 IGF receptor riboprobe was complementary to 15 bases of the $5^{\prime}$ untranslated region, sequences encoding the signal peptide and 53 amino acids of the $\alpha$ subunit coding region cDNA (a gift from $D$. LeRoith, National Institutes of Health, Bethesda, MD) (27). The riboprobe for the type 2 IGF receptor was generated from a clone provided by $\mathrm{M}$. Czech (Department of Biochemistry, University of Massachusetts, Worcester, MA) and was complementary to a region from 260 bases $5^{\prime}$ to 52 bases $3^{\prime}$ of the trans-membrane domain. For IGFBP 1-5, cDNA were amplified from rat liver cDNA with the PCR, using synthetic oligonucleotides as primers (denaturation at $95^{\circ} \mathrm{C}, 2 \mathrm{~min}$; annealed at $55^{\circ} \mathrm{C}, 2 \mathrm{~min}$; and amplified at $72^{\circ} \mathrm{C}$, 2 min for 40 cycles). For IGFBP-1, a PCR product was generated encoding bases $436-791$ of the coding region (28), for IGFBP-2 the PCR product corresponded to bases 613-959 of the coding region (29), for IGFBP-3 a product identical with bases 328-755 of the coding region was generated (30), for IGFBP-4 a PCR product encoding bases 503-703 (7) was produced, and for IGFBP-5 the PCR product was identical with bases 558-1201 (10). The identity of PCR-generated cDNA fragments was confirmed by sequence analysis and was found to be identical with the corresponding published sequences.

Solution hybridization assays. Transcript abundance was determined by solution hybridization assays as previously described (4). TNA samples (2-60 $\mu \mathrm{g}$, depending on the tissue and riboprobe used) were incubated with $15000-65000 \mathrm{cpm} \alpha-{ }^{32} \mathrm{P}-$ labeled antisense RNA probe in a solution containing $0.86 \mathrm{M}$
$\mathrm{NaCl}, 31 \mathrm{mM}$ Tris, $6.4 \mathrm{mM}$ EDTA, 0.2\% SDS, 7.2\% EtOH, and $0.33 \mathrm{mg} / \mathrm{mL}$ herring sperm DNA (total volume $30 \mu \mathrm{L}$ ). Samples were incubated for $\sim 16 \mathrm{~h}$ at $72^{\circ} \mathrm{C}$ before the digestion of singlestranded RNA and unbound riboprobe for $30 \mathrm{~min}$ at $37^{\circ} \mathrm{C}$ with RNAse-A and RNAse-T1 (Boehringer-Mannheim, Indianapolis, IN). Double-stranded nucleotides were precipitated with trichloroacetic acid and radioactivity was quantified after collection on glass fiber filters (Schleicher and Shuell, Keene, NH). The amount of specific RNA precipitated was determined by comparing the radioactivity of the protected RNA with that of a standard curve generated by hybridizing known amounts of the appropriate sense RNA transcript with $\alpha{ }^{32} \mathrm{P}$-labeled riboprobe under identical conditions. Nonspecific hybridization was assessed for each riboprobe and each tissue by analyzing samples of poly(A-) RNA in amounts corresponding to the quantity of total RNA present in TNA samples as previously described (16). Results are expressed as molecules of RNA per cell, assuming a diploid cellular DNA content of $6.4 \mathrm{pg} / \mathrm{cell}$.

Ligand blotting of IGFBP. To assess the abundance of serum IGFBP, ligand blotting of serum was performed as previously described (31). Sera (2 $\mu \mathrm{L})$ were heated in Laemmli buffer (32) to $80^{\circ} \mathrm{C}$ for $3 \mathrm{~min}$ and centrifuged, and the supernatant was sizefractionated by electrophoresis through a $12.5 \%$ discontinuous SDS-polyacrylamide gel under nonreducing conditions. The proteins were then transferred to nitrocellulose membranes (Schleicher and Schuell) and incubated with $300000 \mathrm{cpm}$ each [25I]IGF-I and -II, washed, and exposed to Kodak XAR-5 film (Eastman Kodak, Rochester, NY) at $-70^{\circ} \mathrm{C}$. Autoradiograms were analyzed by densitometry to determine the abundance of each IGFBP species.

Immunoblotting of IGFBP-2. After ligand blotting, nitrocellulose membranes were washed in $50 \mathrm{mM}$ Tris, $0.2 \mathrm{M} \mathrm{NaCl}$, and $3 \%$ BSA and incubated with a 1:2000 dilution of rabbit antiserum raised against bovine IGFBP-2 (a gift of D. R. Clemmons, Department of Medicine, University of North Carolina, Chapel Hill, NC) (33). Protein-antibody conjugates were bound to goat antirabbit $\mathrm{IgG}$ conjugated with alkaline phosphatase (Sigma Chemical Co., St. Louis, MO). Blots were then washed, and sites of second antibody binding were visualized with nitro blue tetrazolium and 5-bromo-4-chloro-3-indoyl-phosphate (Promega, Madison, WI) and photographed. The relative abundance of IGFBP-2 was determined by densitometric analysis of photographic negatives.

Statistical analysis. Means from each group were compared using the Tukey-Kramer multiple comparisons test, and Pearson correlations between continuous variables and Spearman correlations between mixed ordinal and continuous variables were determined using the SYSTAT system for statistics (version 4, Evanston, IL). $p$ values less than 0.05 were considered significant.

\section{RESULTS}

Effect of UAL on fetal survival, growth, and organ weight. Fetuses were collected from two nonop litters and seven experimental litters. There was $100 \%$ fetal survival in the nonop animals and in the UA-nonlig uterine horns and 53\% survival in the UA-lig horn (Table 1). Fetal weight was decreased in pups from both the UA-lig and UA-nonlig uterine horns. Nonop pups demonstrated increasing weights with increasing proximity to the major uterine blood supply (position and body weight correlation for positions $1-5, r=-0.767, p<0.05)$. Pups from the UA-nonlig uterine horn had weights that did not vary significantly with position but were decreased compared with the nonop group at positions $1-2$, nearest the site of uterine manipulation $(p<0.05)$. Fetuses from the UA-lig horns were growth retarded compared with pups from the opposite UA-nonlig uterine horn and compared with nonop control pups. As noted by other investigators (19), the greatest decrease in weight was at positions closest to the vascular disruption (position and body weight correlation, $r=0.704, p<0.05$ ). CRL was not different 
Table 1. Fetal survival, growth, and organ weight*

\begin{tabular}{lccc}
\hline & Nonop & UA-nonlig & UA-lig \\
\hline Survival (\%) & $16 / 16(100)$ & $45 / 45(100)$ & $25 / 45(53) \ddagger \S$ \\
Surviving pups/horn & $4.0 \pm 1.2$ & $6.4 \pm 1.8$ & $3.6 \pm 1.5 \S$ \\
Body wt (g) & $2.8 \pm 0.2$ & $2.5 \pm 0.3 \dagger$ & $2.0 \pm 0.3 \ddagger \S$ \\
CRL (mm) & $33 \pm 1.5$ & $32 \pm 2.0$ & $28 \pm 3.0 \ddagger \S$ \\
Liver wt (mg) & $190 \pm 34$ & $156 \pm 30 \dagger$ & $105 \pm 29 \ddagger \S$ \\
Liver:body wt ratio & $0.067 \pm 0.01$ & $0.062 \pm 0.01 \dagger$ & $0.053 \pm 0.01 \ddagger$ \\
Placenta wt (mg) & $662 \pm 102$ & $524 \pm 86$ & $484 \pm 112 \ddagger \S$ \\
Placenta:body wt ratio & $0.24 \pm 0.04$ & $0.21 \pm 0.04$ & $0.26 \pm 0.06 \S$ \\
\hline
\end{tabular}

$*$ Values are mean $\pm \mathrm{SD}$.

$\dagger p<0.05$ UA-nonlig vs nonop.

$\ddagger p<0.05$ UA-lig vs nonop.

$\S p<0.05$ UA-lig $v s$ UA-nonlig.

in the UA-nonlig and nonop animals but was decreased in pups from the UA-lig uterine horn compared with the UA-nonlig side, with the greatest decrease noted in animals nearest the ligated artery (UA-lig group, CRL, and position, $r=0.531, p<0.05$ ).

Fetal liver weights were decreased $33 \%$ in UA-lig pups compared with UA-nonlig pups, which in turn were $18 \%$ smaller than those of the nonop fetuses $(p<0.05)$. There was a disproportionate decrease in liver weight in the UA-lig group compared with the UA-nonlig pups because the liver:body weight ratio was decreased $15 \%$ in these pups compared with UA-nonlig animals. In addition, liver weight correlated significantly with body weight $(r=0.72, p<0.005)$ in UA-lig animals.

Placental weights were decreased $27 \%$ in the UA-lig group and $21 \%$ in the UA-nonlig group compared with nonop control animals $(p<0.05)$. Although placental weight was smallest in the UA-lig animals, the placental:body weight ratio was higher in the UA-lig than in the UA-nonlig pups $(p<0.005$ compared with UA-nonlig animals). This was due to the greater decrease in body weight in the UA-lig group. Placental weights correlated with body weight in UA-nonlig animals $(r=0.50, p<0.05)$ but did not correlate significantly with body weight in the other two groups.

$m R N A$ transcript abundance. Increases in the abundance of IGFBP-1 and IGFBP-2 mRNA in UA-lig pups were the most dramatic observations. Hepatic IGFBP- 1 mRNA expression in UA-lig animals was increased 2.1-fold $(p<0.005)$ compared with UA-nonlig pups and increased 3.2-fold compared with nonop controls $(p<0.005$, Table 2$)$. In animals from the UAlig uterine horn, IGFBP-1 expression was highest in pups nearest the site of ligation (correlation with position $r=-0.51, p<$ $0.05)$. In nonop control and UA-nonlig animals, mRNA abundance for IGFBP-1 did not vary with position. In all groups combined, fetal body weight correlated with hepatic IGFBP-1 mRNA abundance $(r=-0.66, p<0.005)$.

Hepatic IGFBP-2 was also increased in UA-lig pups (increased 50 and $110 \%$ compared with the UA-nonlig and nonop control groups, respectively; Table 2), but no influence of uterine position was observed. No differences were observed among the groups in IGFBP-3, IGFBP-4, and IGFBP-5 mRNA. Because IGFBP-5 was expressed in very low abundance in liver, near the upper limit of nonspecific hybridization in our assay, small differences among the groups may not have been detected.

IGF-II mRNA expression in liver was increased $31 \%$ in UAlig pups compared with UA-nonlig and $47 \%$ compared with nonop controls (Table 3 ). No significant differences among the groups were observed for the type 1 or type 2 IGF receptors, and IGF-I transcript abundance was below the detectable limits of our assay.

Placenta and carcass expression of mRNA transcripts examined did not follow the same pattern as liver. Except for modest increases in mRNA abundance for carcass IGFBP-3 in operated pups and for carcass IGFBP-2 and IGFBP-4 in the UA-nonlig animals, no significant changes in mRNA abundance for the IGFBP were observed among the groups for placenta and carcass
Table 2. $m R N A$ transcript abundance in fetal liver, placenta, and carcass*

\begin{tabular}{cccc}
\hline & Nonop & UA-nonlig & UA-lig \\
\hline Liver & & & \\
IGFBP-1 & $164 \pm 82(15)$ & $250 \pm 121(37)$ & $526 \pm 228 \ddagger \S(18)$ \\
IGFBP-2 & $80 \pm 26(15)$ & $112 \pm 49(34)$ & $168 \pm 57 \ddagger \S(18)$ \\
IGFBP-3 & $7.6 \pm 2.0(15)$ & $8.2 \pm 4.1(34)$ & $8.3 \pm 3.2(18)$ \\
IGFBP-4 & $10.9 \pm 3.9(13)$ & $14.2 \pm 6.4(33)$ & $14.8 \pm 3.3(16)$ \\
IGFBP-5 & $5.5 \pm 1.9(12)$ & $6.4 \pm 2.7(32)$ & $7.3 \pm 2.4(18)$ \\
Placenta & & & \\
IGFBP-1 & $12.1 \pm 6.4(8)$ & NR & $10.5 \pm 8.0(20)$ \\
IGFBP-2 & $1337 \pm 356(12)$ & $1567 \pm 674(31)$ & $1573 \pm 676(25)$ \\
IGFBP-3 & $34.0 \pm 9.8(11)$ & $36.2 \pm 13(25)$ & $30.0 \pm 14(21)$ \\
IGFBP-4 & NR & NR & NR \\
IGFBP-5 & $8.9 \pm 2.4(9)$ & $9.3 \pm 4.5(25)$ & $9.1 \pm 5.3(19)$ \\
Carcass & & & \\
IGFBP-1 & $31 \pm 12(14)$ & $28 \pm 10(34)$ & $34 \pm 12(17)$ \\
IGFBP-2 & $60 \pm 15(16)$ & $76 \pm 22 \dagger(35)$ & $71 \pm 21(17)$ \\
IGFBP-3 & $76 \pm 15(16)$ & $107 \pm 25 \dagger(35)$ & $102 \pm 16 \ddagger(17)$ \\
IGFBP-4 & $51 \pm 10(16)$ & $60 \pm 13 \dagger(34)$ & $59 \pm 10(17)$ \\
IGFBP-5 & $92 \pm 13(16)$ & $110 \pm 31(34)$ & $104 \pm 19(17)$ \\
\hline
\end{tabular}

* NR, not reported, results below upper limit for nonspecific hybridization. Values are mean $\pm \mathrm{SD}$ (molecules/cell), $n$ in parentheses.

$\dagger p<0.05$ UA-nonlig $v s$ nonop.

$\ddagger p<0.05$ UA-lig $v$ s nonop.

$\S p<0.05$ UA-lig $v s$ UA-nonlig.

(Table 2). In placenta, expression of IGF-II was decreased by $44 \%$ in the UA-lig compared with nonop pups $(p<0.05)$ and, in carcass, mRNA transcript abundance for the type 2 IGF receptor was increased in UA-lig compared with nonop control animals $(p<0.05$, Table 3$)$. The differences observed were not affected by uterine position. Otherwise, no differences were observed between groups in carcass and placenta for the other transcripts measured (Table 3).

Serum IGFBP. Serum IGFBP were analyzed in fetuses from positions 2 and 3 only (because of the small amount of serum collected at other positions). Ligand blots of fetal serum demonstrated an abundant $32000 \mathrm{M}_{\mathrm{r}}$ band representing the IGFBP1/-2 doublet and a 10-fold less prominent $24000 \mathrm{M}_{\mathrm{r}}$ band representing IGFBP-4. Because IGFBP-1 and IGFBP-2 migrate as a doublet band on SDS-PAGE, it is not possible to quantify each band separately by densitometry, and therefore the IGFBP$1 /-2$ doublet was quantified. The IGFBP-1/-2 doublet was increased 2.4-fold and 3.1-fold in UA-lig compared with UA-nonlig and nonop pups, respectively (Table 4). When the same blots were then immunostained for IGFBP-2, no differences in the abundance of this IGFBP were observed among groups. Therefore, the changes in the doublet band observed by ligand blot appear to be due to changes in IGFBP-1. An IGFBP observed migrating at $24 \mathrm{kD}$, and presumed to be IGFBP-4, also was not different among groups.

\section{DISCUSSION}

We observed marked decreases in fetal body weight, liver weight, and placental weight in association with increased hepatic IGFBP- 1 and IGFBP-2 mRNA, increased serum IGFBP-1, and decreased placental IGF-II mRNA in growth-retarded fetuses from the UA-lig uterine horn. Each of these changes may contribute to the pathophysiology of unilateral UAL-induced IUGR.

The stimulus for increased hepatic IGFBP-1 and IGFBP-2 gene expression in UAL-induced growth retardation is not certain. Insulin is known to decrease hepatic IGFBP-1 and IGFBP2 mRNA expression (13), and this hormone's serum concentrations are decreased in IUGR fetuses resulting from UAL (1921), maternal food deprivation (3), and maternal dexamethasone treatment (16). Each of the latter findings supports the idea that hypoinsulinemia is causal in the increased hepatic IGFBP-1 
Table 3. mRNA transcript abundance in fetal liver, placenta, and carcass*

\begin{tabular}{lccc}
\hline & Nonop & UA-nonlig & UA-lig \\
\hline Liver & & & \\
IGF-I & NR & NR & NR \\
IGF-II & $769 \pm 240(15)$ & $865 \pm 372(36)$ & $1130 \pm 444 \ddagger \S(15)$ \\
IGF type 1 receptor & NR & NR & NR \\
IGF type 2 receptor & $145 \pm 39(15)$ & $147 \pm 35(34)$ & $173 \pm 48(18)$ \\
Placenta & $29 \pm 20(13)$ & $23 \pm 13(45)$ & $24 \pm 14(33)$ \\
IGF-I & $1553 \pm 460(13)$ & $1060 \pm 654 \dagger(40)$ & $863 \pm 470 \ddagger(29)$ \\
IGF-II & NR & NR & NR \\
IGF type 1 receptor & $469 \pm 141(12)$ & $606 \pm 306(33)$ & $528 \pm 289(26)$ \\
IGF type 2 receptor & $119 \pm 21(16)$ & $94 \pm 34(35)$ & $99 \pm 39(17)$ \\
Carcass & $514 \pm 84(16)$ & $518 \pm 120(35)$ & $33 \pm 8.1(34)$ \\
IGF-I & $29 \pm 5.1(16)$ & $287 \pm 64 \dagger(34)$ & $33 \pm 5.7(17)$ \\
IGF-II & $219 \pm 55(16)$ & $276 \pm 44 \ddagger(17)$ \\
IGF type 1 receptor & & \\
IGF type 2 receptor & & \\
\hline
\end{tabular}

* NR, not reported, results below upper limit for nonspecific hybridization. Values are mean $\pm \mathrm{SD}$ (molecules/cell), $n$ in parentheses.

$\dagger p<0.05$ UA-nonlig $v s$ nonop.

$\$ p<0.05$ UA-lig vs nonop.

$\S p<0.05$ UA-lig vs UA-nonlig.

Table 4. Relative abundance of fetal serum IGFBP*

\begin{tabular}{lccc}
\hline & $\begin{array}{c}\text { Nonop } \\
(n=3)\end{array}$ & $\begin{array}{c}\text { UA-nonlig } \\
(n=8)\end{array}$ & $\begin{array}{c}\text { UA-lig } \\
(n=5)\end{array}$ \\
\hline IGFBP-1/-2 & $100 \pm 13$ & $126 \pm 44$ & $308 \pm 118 \dagger$ \\
IGFBP-2 & $100 \pm 12$ & $102 \pm 41$ & $123 \pm 37$ \\
IGFBP-4 & $100 \pm 54$ & $108 \pm 27$ & $102 \pm 75$ \\
\hline
\end{tabular}

$*$ Values are expressed as \% nonop control values; mean \pm SD.

$\dagger p<0.05$ vs nonop and UA-nonlig.

expression observed in each of these models of IUGR. IGFBP-1 gene expression, however, also may be regulated by glucose and glucoregulatory hormones $(13,14)$. Other studies have demonstrated that UAL results in decreased serum glucose and amino acid levels and increased glucagon concentrations (17, 18, 22), each of which also could contribute to increased hepatic IGFBP1 expression. The increased abundance of liver IGFBP-1 mRNA in UAL pups was associated with increased serum IGFBP-1, because the liver is thought to be the major source of circulating IGFBP-1. We and others have postulated that increased serum IGFBP-1 may inhibit growth by binding IGF in the circulation and preventing access of IGF to target tissues $(13,16,21)$. Such a mechanism of fetal growth retardation may be a component of IUGR pathophysiology regardless of etiology, because increases in serum IGFBP-1, IGF inhibitory activity, and/or hepatic IGFBP-1 expression have been observed in several models of IUGR $(3,16,22,35)$.

Increased hepatic IGFBP-1 mRNA expression in UAL pups was accompanied by decreased liver size. We have also found increased IGFBP-1 expression in fetal livers and lungs with decreased size resulting from maternal dexamethasone treatment (16), evidence that increased local expression of IGFBP-1 contributes to decreased cellular proliferation in selected organs. We, however, did not observe changes in IGFBP-1 mRNA expression in either carcass or placenta, arguing that this mechanism does not mediate growth retardation in all tissues. On the other hand, serum-borne IGFBP-1 has been shown to cross intact vascular endothelium in adult rats $(36,37)$, and thus excess serum IGFBP1 , as seen in our model, may enter tissue and inhibit IGF action in tissues where IGFBP-1 mRNA expression is not increased. Whether this mechanism contributes to the decreased growth in carcass and placenta awaits quantitation of tissue IGFBP-1 concentrations.

Hepatic IGF-II mRNA expression in UA-lig pups was modestly increased (31\%), a finding consistent with the observations of others that serum IGF-II is increased in animals with IUGR caused by carunculectomy, fetal pancreatectomy, and UAL (22,
35, 38, 39). However, the relationship between serum IGF-II and IUGR is complicated by observations of decreased or unchanged serum IGF-II and hepatic IGF-II expression in fetuses with IUGR resulting from maternal fasting or protein restriction $(3,4,22)$. Taken together with our findings in nutritionally deprived UAL fetuses, it does not appear that nutrition is a major regulator of fetal hepatic IGF-II expression or that reduced serum IGF-II has a role in the pathophysiology of IUGR in these models.

The decline in IGF-II mRNA abundance in placentas from UAL pups observed in this study could contribute to decreased placental growth and lead to placental insufficiency, perhaps the major reason for decreased fetal growth after UAL. The importance of placental IGF-II expression in the growth retardation of this organ is supported by observations that IGF-II is expressed in placenta from early in gestation (40) and that IUGR mice with a disrupted IGF-II allele and absent placental IGF-II expression have very small placentas (41). IGFBP-2 also may play a role in placental growth, inasmuch as it is expressed in high levels in normal placentas (42) and expression remains high in IUGR when IGF-II mRNA abundance declines. The usual pattern of concordance between IGF-II and IGFBP-2 expression in the rat during development (13) and the high affinity of IGFBP2 for IGF-II suggest that IGFBP-2 helps modulate the local availability of IGF-II. Although maintenance of placental IGFBP-2 expression may be a mechanism for preserving local concentrations of IGF-II in the face of decreased IGF-II expression, increased IGFBP-2 relative to IGF-II instead may decrease IGF-II bioavailability, contributing to decreased cell proliferation in the placenta.

Pups from the UA-nonlig uterine horn exhibited small increases in carcass IGFBP-2 and IGFBP-4 mRNA abundance. Similar increases were found in UA-lig fetuses but did not reach statistical significance because of fewer observations in that group. It is known that anesthesia and uterine manipulation without UAL transiently decrease maternal food intake and fetal glucose concentrations (18). The increased expression of IGFBP2 and IGFBP-4 mRNA in carcass may reflect these metabolic alterations. Because we measured whole tissue mRNA, the observed changes in IGFBP mRNA abundance may indicate physiologically significant changes within specific tissues of the carcass or within specific cell populations of those tissues. Studies using in situ hybridization histochemistry will be required to demonstrate such cell-specific changes in mRNA abundance.

Our results demonstrate contrasts in the regulation of mRNA abundance for the IGFBP among tissues. In addition to the tissue-specific changes in IGFBP-1 and IGFBP-2 mRNA abundance in IUGR fetuses, we observed increased IGFBP-3 mRNA 
expression in carcass but not in the placenta or liver. Although it is unclear whether increased IGFBP-3 mRNA occurs in all carcass tissues or is specific to one tissue component of connective tissue, these findings support the concept that local regulation of IGFBP production modulates IGF autocrine/paracrine activity in a tissue-specific manner.

With the exception of the assessment of serum IGFBP concentrations, our study did not address whether there were changes in the expression of the proteins encoded by the mRNA studied. Regulation of mRNA translation and/or regulation of the processing of the proteins they encode could dramatically alter protein abundance and, in turn, alter fetal growth. When evaluated, IGF and IGFBP expression have correlated well with steady-state mRNA abundance; nonetheless, assessment of tissue IGF and IGFBP concentrations and quantitation of IGF receptor number will be necessary to determine whether there are changes in protein expression. Our observation of increased carcass type 2 receptor mRNA in operated pups, if accompanied by an increase in functional type 2 IGF receptors, could increase IGF turnover because this receptor is known to transport IGF and other proteins to lysosomes where they are presumably degraded. Such a mechanism could alter IGF abundance independent of mRNA expression and contribute to growth retardation.

\section{REFERENCES}

1. D'Ercole AJ 1991 The insulin-like growth factors and fetal growth. In: Spencer EM (ed) Modern Concepts of Insulin-like Growth Factors, Vol 1. Elsevier, New York, pp 9-24

2. Hill DJ, Fekete M, Milner D 1983 Reduced plasma somatomedin activity during experimental growth retardation in the fetal and neonatal rat. In: Spencer EM (ed) Insulin-like Growth Factors/Somatomedins. de Gruyter, Berlin, $\mathrm{p}$ 345-356

3. Straus DS, Ooi GT, Orlowski CC, Rechler MM 1991 Expression of the genes for insulin-like growth factor-1 (IGF-I), IGF-II, and IGF-binding proteins-1 and -2 in fetal rat under conditions of intrauterine growth retardation caused by maternal fasting. Endocrinology 128:518-525

4. Davenport ML, D'Ercole AJ, Underwood LE 1990 Effect of maternal fasting on fetal growth, serum insulin-like growth factors (IGFs), and tissue IGF messenger ribonucleic acids. Endocrinology 126:2062-2067

5. Bernstein IM, DeSouza MM, Copeland KC 1991 Insulin-like growth factor I in substrate-deprived, growth-retarded fetal rats. Pediatr Res 30:154-157

6. Brewer MT, Stetler GL, Squires CH, Thompson RC, Busby WH, Clemmons DR 1988 Cloning, characterization, and expression of a human insulin-like growth factor binding protein [published erratum appears in Biochem Biophys Res Commun 1988 155:1485]. Biochem Biophys Res Commun 152:1289-1297

7. Shimasaki S, Uchiyama F, Shimonaka M, Ling N 1990 Molecular cloning of the CDNAs encoding a novel insulin-like growth factor-binding protein from rat and human. Mol Endocrinol:4:1451-1458

8. Wood WI, Cachianes G, Henzel WJ, Winslow GA, Spencer SA, Hellmiss R, Martin JL, Baxter RC 1988 Cloning and expression of the growth hormonedependent insulin-like growth factor-binding protein. Mol Endocrinol 2:1176-1185

9. Binkert C, Landwehr J, Mary J-L; Schwander J, Heinrich G 1989 Cloning, sequence analysis and expression of a cDNA encoding a novel insulin-like growth factor binding protein (IGFBP-2). EMBO J 8:2497-2502

10. Shimasaki S, Shimonaka M, Zhang H-P, Ling N 1991 Identification of five different insulin-like growth factor binding proteins (IGFBPs) from adult rat serum and molecular cloning of a novel IGFBP-5 in rat and human. J Biol Chem 266:10646-10653

11. Kiefer MC, Masiarz FR, Bauer DM, Zapf J 1991 Identification and molecular cloning of two new $30-\mathrm{kDa}$ insulin-like growth factor binding proteins isolated from adult human serum. J Biol Chem 266:9043-9049

12. Lewitt MS, Denyer GS, Cooney GJ, Baxter RC 1991 Insulin-like growth factorbinding protein-1 modulates blood glucose levels. Endocrinology 129:22542256

13. Clemmons DR 1991 Insulin-like growth factor binding proteins. In: LeRoith $\mathrm{D}$ (ed) Insulin-like Growth Factors. CRC Press, Boston, pp 151-180

14. Straus DS, Takemoto CD 1990 Effect of dietary protein deprivation on insulinlike growth factor (IGF)-I and -II, IGF binding protein-2, and serum albumin gene expression in rat. Endocrinology 127:1849-1860

15. Ricciarelli E, Hernandez ER, Hurwitz A, Kokia E, Rosenfeld RG, Schwander J, Adashi EY 1991 The ovarian expression of the antigonadotropic insulinlike growth factor binding protein-2 is theca-interstitial cell-selective: evidence for hormonal regulation. Endocrinology 129:2266-2268

16. Price WA, Stiles AD, Moats-Staats BM, D'Ercole AJ 1992 Gene expression of insulin-like growth factors (IGFs), the type 1 IGF receptor and IGF binding proteins in dexamethasone-induced fetal growth retardation. Endocrinology $130: 1424-1432$
17. Nitzan M, Orloff S, Schulman JD 1979 Placental transfer of analogs of glucose and amino acids in experimental intrauterine growth retardation. Pediatr Res 13:100-103

18. Ogata ES, Bussey ME, Finley S 1986 Altered gas exchange, limited glucose and branched chain amino acids, and hypoinsulinemia retard fetal growth in the rat. Metabolism 35:970-977

19. De Prins FA, Hill DJ, Fekete M, Robsen DJ, Fieller NR, Van Assche FA, Milner RD 1984 Reduced plasma somatomedin activity and costal cartilage sulfate incorporation activity during experimental growth retardation in the fetal rat. Pediatr Res 18:1100-1104

20. Vileisis RA, D'Ercole AJ 1986 Tissue and serum concentrations of somatomedin-C/insulin-like growth factor $I$ in fetal rats made growth retarded by uterine artery ligation. Pediatr Res 20:126-130

21. Unterman $T$, Lascon R, Gotway MB, Oehler D, Gounis A, Simmons RA Ogata ES 1990 Circulating levels of insulin-like growth factor binding protein-1 (IGFBP-1) and hepatic mRNA are increased in the small for gestational age (SGA) fetal rat. Endocrinology 127:2035-2037

22. Jones CT, Lafeber HN, Rolph TP, Parer JT 1990 Studies on the growth of the guinea pig. The effects of nutritional manipulation on prenatal growth and plasma somatomedin activity and insulin-like growth factor concentrations. J Dev Physiol 13:189-197

23. Wigglesworth JC 1964 Experimental growth retardation in the foetal rat. J Pathol Bacteriol 88:1-13

24. Durnam DM, Palmiter RP 1983 A practical approach for quantitating specific mRNAs by solution hybridization. Anal Biochem 131:385-393

25. Casella SJ, Smith EP, Van Wyk JJ, Joseph DR, Hynes MA, Hoyt EC, Lund PK 1987 Isolation of rat testis cDNAs encoding somatomedin-C/insulinlike growth factor I precursor. DNA 6:325-330

26. Whitfield HJ, Bruni CB, Frunzio R, Terrell JE, Nissley SP, Rechler MM 1984 Isolation of a cDNA clone encoding rat insulin-like growth factor-II precursor. Nature 312:277-280

27. Werner H, Woloschak M, Adamo M, Shen-Orr Z, Roberts CT, Jr., LeRoith D 1989 Developmental regulation of the rat insulin-like growth factor receptor gene. Proc Natl Acad Sci USA 86:7451-7455

28. Murphy LJ, Seneviratne C, Ballejo G, Croze F, Kennedy TG 1990 Identification and characterization of a rat decidual insulin-like growth factor binding protein cDNA. Mol Endocrinol 4:329-336

29. Brown AL, Chiariotti L, Orlowski CC, Mehlman T, Burgess WH, Ackerman EJ, Bruni CB, Rechler MM 1989 Nucleotide sequence and expression of a cDNA clone encoding a fetal rat binding protein for insulin-like growth factors. J Biol Chem 264:5148-5154

30. Albiston AL, Herington AC 1990 Cloning and characterization of the growth hormone-dependent insulin-like growth factor binding protein (IGFBP-3) in the rat. Biochem Biophys Res Commun 166:892-897

31. Hill DJ, Camacho-Hubner C, Rashid P, Strain AJ, Clemmons DR 1989 Insulin-like growth factor (IGF)-binding protein release by human fetal fibroblasts: dependency on cell density and IGF peptides. J Endocrinol 122:87-98

32. Laemmli UK 1970 Cleavage of structural protein during assembly of the head bacteriophage T4. Nature 227:680-685

33. Busby WH, Snyder DK, Clemmons DR 1988 Radioimmunoassay of a 26,000 dalton plasma insulin-like growth factor-binding protein: control by nutritional variables. J Clin Endocrinol Metab 67:1225-1230

34. Murphy LJ, Seneviratne C, Moreira P, Reid RE 1991 Enhanced expression of insulin-like growth factor-binding protein-I in the fasted rat: the effects of insulin and growth hormone administration. Endocrinology 128:689-696

35. Lafeber HN, Jones CT, Price DA 1987 Studies on the growth of the fetal guinea pig, Changes in the plasma concentration of sulphation-promoting activity and of insulin-like growth factors during gestation. J Dev Physiol 9:169-179

36. Bar RS, Boes M, Clemmons DR, Busby WH, Sandra A, Dake BL, Booth BA 1990 Insulin differentially alters transcapillary movement of intravascular IGFBP-1, IGFBP-2 and endothelial cell IGF-binding proteins in the rat heart. Endocrinology 127:497-499

37. Bar RS, Clemmons DR, Boes M, Busby WH, Booth BA, Dake BL, Sandra A 1990 Transcapillary permeability and subendothelial distribution of endothelial and amniotic fluid insulin-like growth factor binding proteins in the rat heart. Endocrinology 127:1078-1086

38. Jones CT, Gu W, Harding JE, Price DA, Parer JT 1988 Studies on the growth of the fetal sheep. Effects of surgical reduction in placental size, or experimental manipulation of uterine blood flow on plasma sulphation promoting activity and on the concentration of insulin-like growth factors I and II. J Dev Physiol 10:179-189

39. Gluckman PD, Butler JH, Comline R, Fowden A 1987 The effects of pancreatectomy on the plasma concentrations of insulin-like growth factors 1 and 2 in the sheep fetus. J Dev Physiol 9:79-88

40. Lee JE, Pintar J, Efstratiadis A 1990 Pattern of the insulin-like growth factor II gene expression during early mouse embryogenesis. Development 110:151-159

41. DeChiara TM, Efstratiadis A, Robertson EJ 1990 A growth-deficiency phenotype in heterozygous mice carrying an insulin-like growth factor II gene disrupted by targeting. Nature 345:78-80

42. Margot JB, Binkert C, Mary J-L, Landwehr J, Heinrich G, Schwander J 1992 A low molecular weight insulin-like growth factor binding protein from rat: cDNA cloning and tissue distribution of its messenger RNA. Mol Endocrinol 3:1053-1063 